\title{
Strains of Uronema marinum (Scuticociliatia) co-isolated with amoebae of the genus Neoparamoeba
}

\author{
Iva Dyková ${ }^{1,2, *}$, Tomáš Tyml ${ }^{1,2}$, Martin Kostka ${ }^{1,3}$, Hana Pecková ${ }^{1}$ \\ ${ }^{1}$ Institute of Parasitology, Biology Centre, Academy of Sciences of the Czech Republic, 37005 České Budějovice, \\ Czech Republic \\ ${ }^{2}$ Faculty of Science, and ${ }^{3}$ Faculty of Agriculture, University of South Bohemia, 37005 České Budějovice, Czech Republic
}

\begin{abstract}
Mixed infections of histophagous ciliates and Neoparamoeba spp. Page, 1987 were diagnosed in gill tissue of farmed turbot Psetta maxima (synonym: Scophthalmus maximus) and Atlantic salmon Salmo salar during a study of amoebic gill disease. Ciliates co-isolated from lesions grossly visible on gills of both fish hosts and from 2 species of red algae Lithophyllum racemus and Palmaria palmata were characterized morphologically and by using molecular markers. Sequences of small subunit (SSU) rDNA were determined for 6 strains of ciliates isolated from hosts collected in geographically distant localities. Of these, sequences of 5 strains revealed a surprisingly high level of similarity and identified the corresponding strains with Uronema marinum Lynn et Small, 1997. Thus, the set of environmental sequences of $U$. marinum available in the GenBank database to date was supplemented with the first sequences of potentially histophagous strains. On the basis of SSU rDNA, the 6th strain, also isolated from affected fish gills, was identified as Aristerostoma sp.
\end{abstract}

KEY WORDS: Uronema marinum $\cdot$ SSU rDNA $\cdot$ Histophagous strains

\section{INTRODUCTION}

Marine scuticociliates described as free-living organisms and symbionts or 'harmless' commensals of invertebrates are well known also as primary agents causing serious disease conditions, both in invertebrate and fish hosts (Cheung et al. 1980, Dyková \& Figueras 1994, Dragesco et al. 1995, Cawthorn et al. 1996, Munday et al. 1997, Crosbie \& Munday 1999, Alvarez-Pellitero et al. 2004, Kim et al. 2004a,b, Paramá et al. 2006, Rossteuscher et al. 2008). Etiological studies of amoebic gill disease (AGD) that focused on the isolation of the agent of AGD from gill tissues turned our attention to ciliates that were found in primary isolates together with Neoparamoeba spp. (Dyková et al. 1999, Dyková \& Novoa 2001). Since the ciliates were found in mixed infections with trophozoites of Neoparamoeba spp. and also in histological sections of affected gill tissues of turbot Psetta maxima (synonym: Scophthalmus maximus) and Atlantic salmon Salmo salar, exact determination of the identity of ciliates established in cultures became of great interest.

\section{MATERIALS AND METHODS}

Primary isolation, culture and subculture of ciliates. Ciliates included in this study were isolated together with amoebae of the genus Neoparamoeba Page, 1987 in the course of extensive screening of fish gill tissues for the presence of an agent of AGD and during the search for amoebae of the genus Paramoeba Schaudinn, 1896 in invertebrate and environmental samples from 1996 to 2008. Generic assignment of amoeba strains was based on light and electron microscopic observation. Species determination of $3 \mathrm{NeO}$ paramoeba strains was supplemented with molecular 
characterization (Dyková et al. 2007, 2008). Ciliates included in the present study are listed in Table 1. This set of strains contains only those co-isolated with Neoparamoeba strains from a same sample (gill tissue or organic material covering the surface of red algae). Non-nutrient $75 \%$ seawater agar (BD Bacto ${ }^{\mathrm{TM}}$ Agar) was routinely used for primary isolations. To establish the ciliates in culture, a clean population of each isolate of ciliates was selected with the aid of a light microscope and transferred (together with piece of agar) to MY75S (Malt \&Yeast Extract-75\% seawater) medium (catalogue of the UK National Culture Collection). The same medium was used for the cloning procedures carried out in cell wells at $20^{\circ} \mathrm{C}$. For subculturing of ciliates, initially MY75S medium supplemented with autoclaved pieces of freshwater fish gill tissue was used. Later, the ciliates were fed fathead minnow Pimephales promelas (FHM) cell line cells. Culture medium used for the FHM cell line was removed from each culture flask and substituted with MY75S medium containing ciliates of the parent culture. Ciliates were subcultured weekly. Both methods of subculturing were used alternately with varying success.

Morphological characterization of ciliates. Gross morphological features of living ciliates were observed with light microscopy by means of Nomarski differential interference contrast. Details of ciliature, not visible in living specimens, were studied in stained preparations and with scanning electron microscopy (SEM). For purposes of SEM, ciliates were fixed in $3 \%$ cacodylate buffered glutaraldehyde, washed in $0.1 \mathrm{M}$ cacodylate buffer and postfixed with $1 \%$ osmium tetroxide. Samples were dehydrated in a graded acetone series, critical-point dried with liquid $\mathrm{CO}_{2}$, sputter-coated with gold-palladium and examined with a JEOL 6700F electron microscope. The wet silver nitrate method by Chatton and Lwoff as described in Foissner (1991) and the ammoniacal silver carbonate method (FernándezGaliano 1994) were used for morphological studies of clonal cultures of individual strains. To eliminate negative influence of salts from the culture medium, repeated washing of samples was applied in both methods after ciliates were fixed.
DNA isolation, amplification and sequencing. Genomic DNA was extracted from pelleted ciliates using the JETQUICK Tissue DNA Spin Kit (Genomed) according to the manufacturer's protocol. Universal eukaryotic primers (5'-ACC TGG TTG ATC CTG CCA G-3' and 5'-CTT CCG CAG GTT CAC CTA CGG-3') reported by Barta et al. (1997) were used for amplification of the small subunit (SSU) rRNA gene. PCR was carried out in a $25 \mu \mathrm{l}$ reaction volume using $1 \mu \mathrm{M}$ of each primer, $200 \mu \mathrm{M}$ of each dNTP, $2.5 \mu \mathrm{l}$ of $10 \times$ Taq polymerase buffer and 1 unit of TaqDNA polymerase (Top-Bio). The PCR amplification was performed with a Tpersonal Thermocycler (Biometra). The cycling conditions were as follows: initial 5 min denaturation at $95^{\circ} \mathrm{C}$ followed by 5 amplification cycles (each comprising $94^{\circ} \mathrm{C}$ for $1 \mathrm{~min}, 44^{\circ} \mathrm{C}$ for $1.5 \mathrm{~min}$ and $72^{\circ} \mathrm{C}$ for $2 \mathrm{~min}$ ), and another 25 cycles (each comprising $94^{\circ} \mathrm{C}$ for $1 \mathrm{~min}, 48^{\circ} \mathrm{C}$ for $1.5 \mathrm{~min}$ and $72^{\circ} \mathrm{C}$ for $2 \mathrm{~min}$ ). The final $10 \mathrm{~min}$ extension ran at $72^{\circ} \mathrm{C}$. The amplified products were purified from $1 \%$ agarose gel using JETQUICK Gel Extraction Spin Kit (Genomed) and cloned into pDrive Cloning Vector using the QIAGEN PCR Cloning Kit (Qiagen $\mathrm{GmbH}$ ). Sequencing was carried out on an automatic sequencer ABI $3130 \times 1$ using the ABI PRISM BigDye Terminator v. 3.1 Cycle Sequencing Kit (Applied Biosystems).

The forward primer G-FOR 5'-GGG ATC CGT TTC CGT AGG TGA ACC TGC-3' and reverse G-REV 5'GGG ATC CAT ATG CTT AAG TTC AGC GGG T-3' (Coleman \& Vacquier 2002) were used for PCR amplification of the whole internal transcribed spacer (ITS) region (ITS1, 5.8S and ITS2). The cycling conditions included an initial 5 min denaturation at $95^{\circ} \mathrm{C}$ followed by 30 cycles of a $1 \mathrm{~min}$ denaturation at $95^{\circ} \mathrm{C}$, a $2 \mathrm{~min}$ annealing at $46^{\circ} \mathrm{C}$, a 1 min extension at $72^{\circ} \mathrm{C}$ and a final 10 min extension at $72^{\circ} \mathrm{C}$.

Phylogenetic analysis. To determine phylogenetic relationships of SSU rDNA sequences representing our strains of ciliates and those available from the GenBank database, the following methods were employed. The alignment was prepared in ClustalX 2.0.6 (Larkin et al. 2007). Ambiguously aligned positions were deleted manually in BioEdit (Hall 1999). The resulting alignment

Table 1. Denomination and origin of strains of ciliates co-isolated with Neoparamoeba strains. Generic assignment of amoebae co-isolated with CTAS/I, CTAS2/II and CTAS4/I was based on morphology of trophozoites

\begin{tabular}{|lllcl|}
\hline Strain/clone & Host species & Geographic origin & Sample origin & Co-isolated amoeba \\
\hline CESP/I & Psetta maxima & Atlantic Ocean, NW Spain farm & Gills & N. pemaquidensis AFSM2/I \\
CTAS/I & Salmo salar & Tasman Sea, floating sea cages & Gills & Neoparamoeba sp. \\
CTAS2/II & Salmo salar & Tasman Sea, floating sea cages & Gills & Neoparamoeba sp. \\
CTAS4/I & Salmo salar & Tasman Sea, floating sea cages & Gills & Neoparamoeba sp. \\
CLIT/I & Lithophyllum racemus & Adriatic Sea, Croatia & & N. pemaquidensis LITHON/I \\
CPAL2/I & Palmaria palmata & Norwegian Sea, reg. Trondheim & & N. pemaquidensis PAL2/I \\
\hline
\end{tabular}


contained 1648 positions. Maximum likelihood (ML) analyses were performed with the program $\mathrm{RA} \times \mathrm{ML}$ 7.0.3 (Stamatakis 2006) with the use of GTR $+\Gamma$ model and rapid bootstrapping (100 replicates). Program PAUP* 4.0b10 (Swofford 2000) was used to compute maximum parsimony (MP) analyses. Heuristic searches were conducted with 10 repeated searches in which the starting tree was constructed by random taxa addition and swapped with the tree bisection-reconnection (TBR) algorithm. The number of bootstrap replicates was 1000 .

\section{RESULTS}

During our study of AGD, a limited number of mixed infections of ciliates and amoebae of the genus Neoparamoeba was diagnosed histologically (Fig. 1) compared with the number of samples used for isolation attempts. Co-isolation of ciliates and free-living amoebae from samples of gill tissues occurred quite frequently. Of 40 primary isolates of Neoparamoeba spp., $22(55 \%)$ were accompanied by ciliates. If present, ciliates started to multiply as soon as the decay of gill tissue samples began after being placed with pieces of algae on the surface of agar plates. Actively moving and multiplying ciliates were always restricted to liquefying parts of tissue samples (Fig. 2). As the the quantity of liquid gradually decreased, trophozoites became less active and more rounded.

Five of six strains of ciliates co-isolated with Neoparamoeba spp. included in this study revealed a conspicuous similarity in their morphology (see Figs. 1, 3 \& 4 for details). Trophozoites were ovoid to elongateovoid with an estimated maximum body length and width averaging 24.2 and $10.1 \mu \mathrm{m}$, respectively. Somatic ciliature revealed holotrichous distribution with 14 somatic kineties (Fig. 7). The oral region was in the anterior half of the cell (Figs. $6 \&$ 8). Oral ciliature was relatively inconspicuous. Scutica, the hook-like configuration of kinetosomal structure, was observed in specimens impregnated with the wet silver nitrate method. A globular to ellipsoid macronucleus was located midlength along the body and the micronucleus in its vicinity was visualized by the ammoniacal silver carbonate method (Figs. 10 \& 11). A single contractile vacuole was located in the posterior half of the body (Fig. 5). Caudal cilium was not clearly seen in any individual observed. Based on these morphological features, clonal cultures of 5 strains (CLIT, CESP, CPAL2, CTAS and CTAS4) were assigned to the genus
Uronema Dujardin, 1841. Unfortunately, we did not succeed in cryopreservation of these Uronema strains although repeated attempts were made by means of various protocols. However, samples of DNA are stored in our collection.

The 6th strain (CTAS2) was included in this study on the basis of superficial morphological similarities observed in the living individuals; nevertheless, it differed from the other strains in stained preparations. The results obtained using the same staining procedures did not seem sufficient for the generic assignment of this strain on the basis of morphological features. Unlike the previous group of strains, cryopreservation of CTAS2 strain was successful and samples of DNA were also stored.

Sequences of SSU rDNA and internal spacers (ITS1, ITS2) that were determined for the strains studied have been deposited in the GenBank database. Accession numbers of sequences are listed and sequence lengths are summarized in Table 2.

Phylogenetic analyses based on SSU rDNA revealed a close relationship of sequences of 5 strains of ciliates morphologically assigned to the genus Uronema and positioned them to the well-supported clade of Uronema marinum (Fig. 12). Within this clade, the sequences of 4 strains (CESP, CLIT, CPAL2 and CTAS) were of identical length, consisting of $1751 \mathrm{bp}$ (SSU rDNA) and $484 \mathrm{bp}$ (ITS). The sequence of the CESP strain differed in only one nucleotide in the ITS2 region. In the sequences of CTAS4 there were 8 differences in the ITS1 region and 6 in ITS2, although the total length of both ITS and SSU rDNA differed by one nucleotide only (485 and $1752 \mathrm{bp}$, respectively).

The sequence of the CTAS2 strain isolated from gills of Atlantic salmon branched as a sister sequence of Aristerostoma sp. (EU264563). Together with the sequence of $A$. marinum (EU264562) obtained by Dunthorn et al. (2009), it formed a well-supported clade. Although we were unable to determine the CTAS2 strain morphologically, the unambiguous result of phylogenetic analysis provided a basis of assignment of the strain CTAS2 to the genus Aristerostoma Kahl, 1931.

Table 2. Strains of ciliates, ordered by the base pair length of their internal transcribed spacer (ITS) and small subunit (SSU) rDNA sequences

\begin{tabular}{|lllllll|}
\hline \multicolumn{2}{l}{ Strain/clone ITS1 } & $5.8 \mathrm{~S}$ & ITS2 & Total ITS & SSU & Accession nos. ITS/SSU \\
\hline CESP/I & 133 & 120 & 231 & 484 & 1751 & GQ259754/GQ259744 \\
CLIT/I & 133 & 120 & 231 & 484 & 1751 & GQ259751/GQ259745 \\
CPAL2/I & 133 & 120 & 231 & 484 & 1751 & GQ259752/GQ259746 \\
CTAS/I & 133 & 120 & 231 & 484 & 1751 & GQ259753/GQ259747 \\
CTAS4/I & 134 & 120 & 231 & 485 & 1752 & GQ259755/GQ259749 \\
CTAS2/II & & & & 632 & 1754 & GQ259750/GQ259748 \\
\hline
\end{tabular}




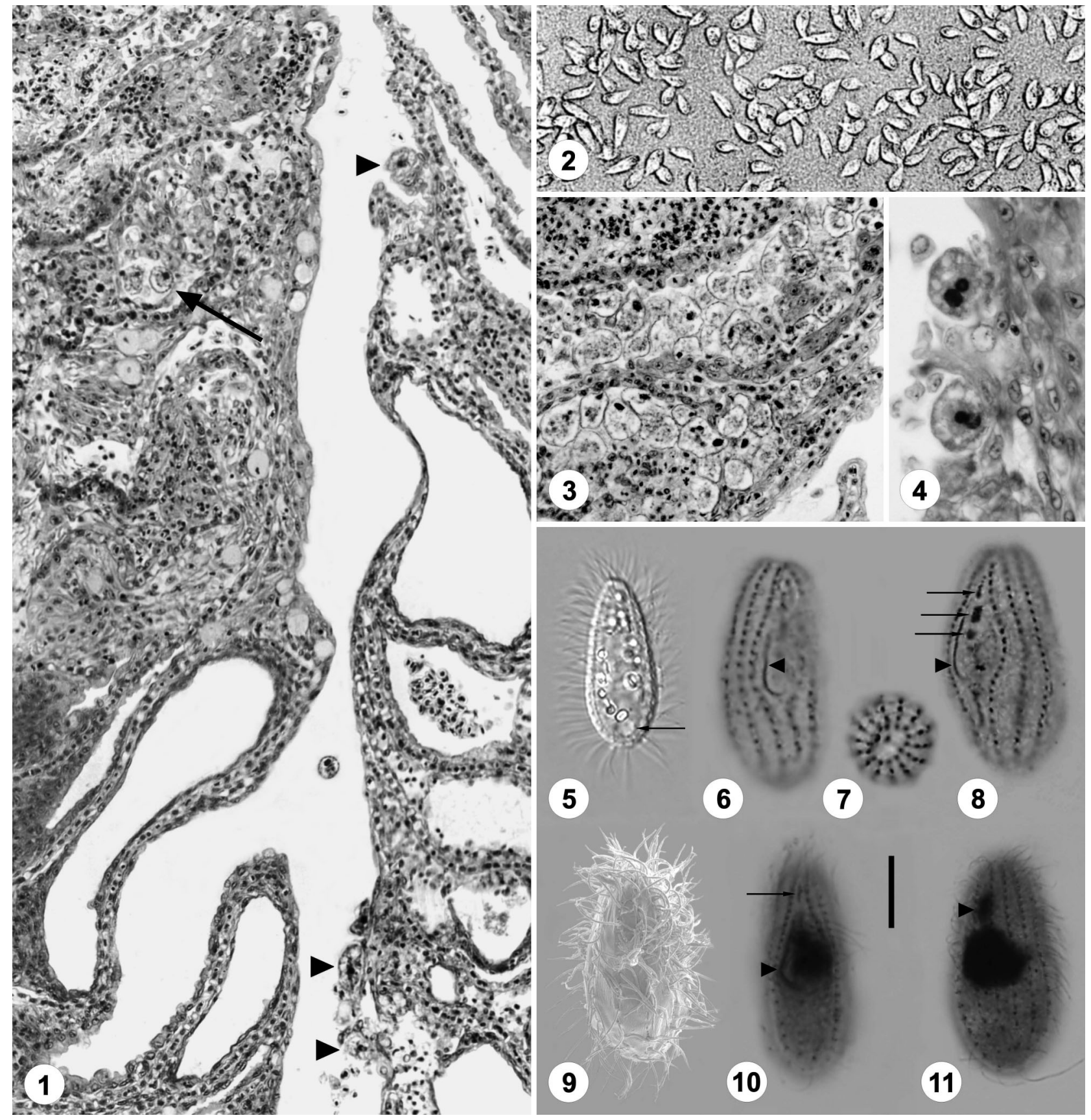

Fig. 1. Psetta maxima. Mixed gill infection of histophagous ciliates and Neoparamoeba sp. in turbot. Arrow indicates ciliates in the interlamellar epithelium; arrowheads mark attached trophozoites of Neoparamoeba sp. Low magnification was used to document the mixed infection in one field of view. Stained with haematoxylin and eosin (H\&E). Magnification $\times 130$. Fig. 2. Trophozoites of histophagous ciliates co-isolated with Neoparamoeba sp. as seen on the surface of an agar plate. Fig. 3. Detail of ciliates localised in the interlamellar epithelium of the sample shown in Fig. 1. Stained with H\&E. Magnification $\times 220$. Fig. 4. Trophozoites of Neoparamoeba sp. attached to the surface of hyperplastic epithelium of the sample shown in Fig. 1. Stained with H\&E. Magnification $\times 570$. Figs. 5 to 11. Uronema marinum. Morphological features of isolated strains. Fig. 5. Live trophozoite of CTAS4 strain as observed in Nomarski DIC; arrow points at the contractile vacuole. Figs. 6 to 8. Wet silver nitrate impregnation demonstrating buccal apparatus and longitudinal kineties in lateral and apical views (CTAS4 strain). Arrowheads point at the paroral membrane. Fine arrows point at the 3 oral polykinetids in Fig. 8. Fig. 9. Trophozoite of CESP strain as seen in SEM in ventral view. Figs. $10 \& 11$. Silver carbonate impregnated trophozoites of the strain CTAS4. Fine arrow marks 1 oral polykinetid in Fig. 10; arrowhead marks paroral membrane in Fig. 11. Arrowhead marks micronucleus side to macronucleus. Scale bar $=10 \mu \mathrm{m}$ for Figs. 5 to 11 


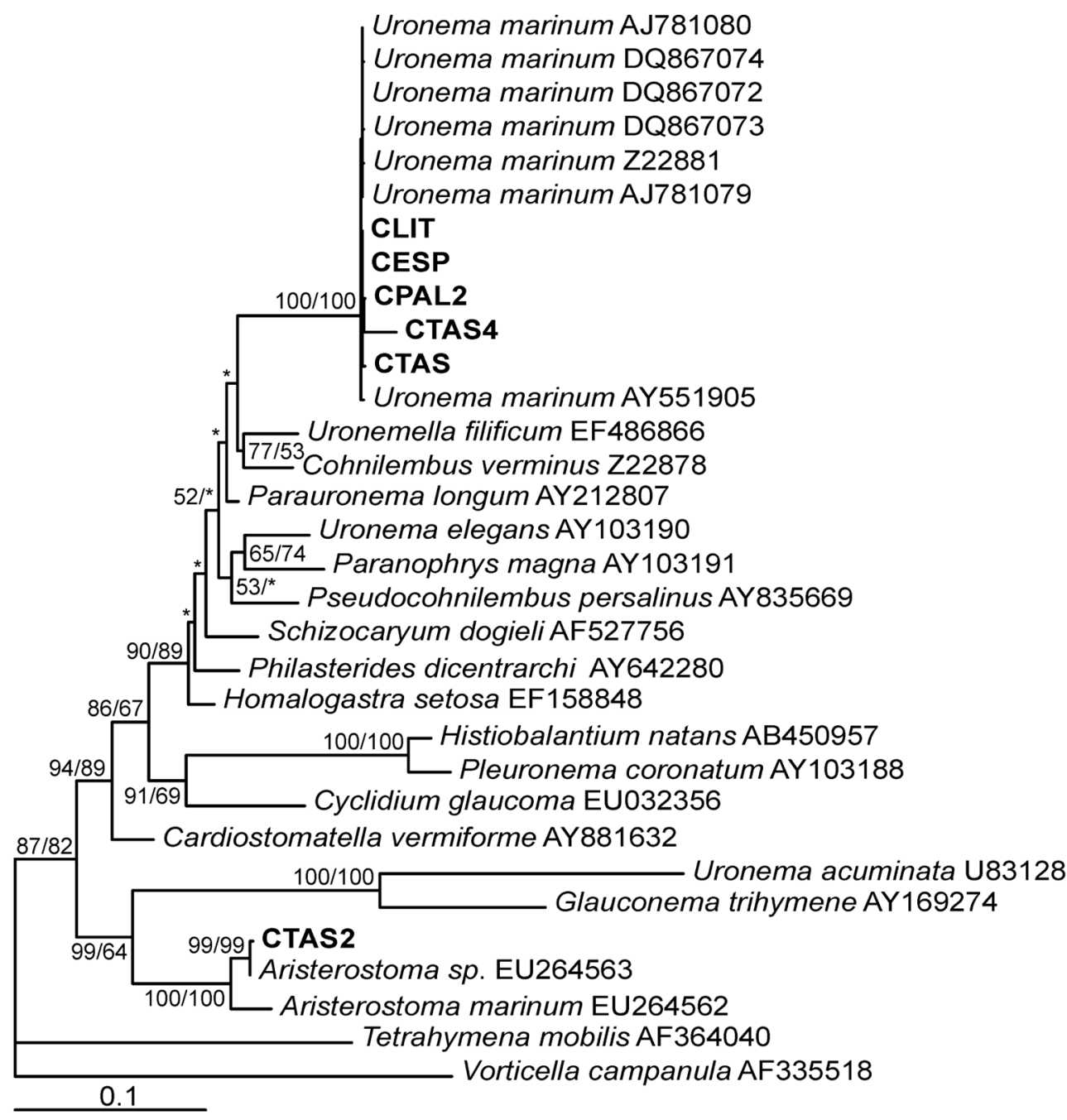

Fig. 12. Phylogenetic tree resulting from maximum likelihood (ML) analysis of a dataset comprising 30 SSU rDNA sequences of philasterid ciliates plus 2 outgroups. Six sequences determined in the present study are indicated in bold text. Numbers at the nodes are bootstrap values for ML/maximum parsimony analysis, respectively. Asterisks $\left({ }^{*}\right)$ represents bootstrap values $<50$. (Note: Philasterides dicentrarchi is a junior synonym of Miamiensis avidus)

\section{DISCUSSION}

The role of several species of histophagous ciliates has been studied in relation to their effect on the health of ornamental fish (Cheung et al. 1980, Bassleer 1983, Rossteuscher et al. 2008) and on farmed fish species, especially seabass Dicentrarchus labrax (Dragesco et al. 1995), southern bluefin tuna Thunnus maccoyii (Munday et al. 1997), turbot (Iglesias et al. 2001, Paramá et al. 2003) and olive flounder Paralichthys olivaceus (Kim et al. 2004a,b, Jung et al. 2007). Philasterides dicentrarchi, which is considered to be a junior synonym of $\mathrm{Mi}$ amiensis avidus (Jung et al. 2007), has been frequently reported as an agent of systemic infections, including those that infect gills. This species has been characterized in detail, both morphologically and at a molecular level (Jung et al. 2005). A highly invasive and destructive ciliate similar to free-living Uronema marinum has been described from Atlantic and Pacific marine fishes kept in the New York Aquarium (Cheung et al. 1980). Uronema-like ciliates have been reported as agents of severe outbreaks of systemic infections in farmed turbot (Sterud et al. 2000). Also amoebae of the genus Neoparamoeba have been widely reported as a cause of serious problems in farmed turbot, but unlike scuticociliates, they were always restricted to gill lesions. The primary role of Miamiensis avidus in gill scuticociliatosis (Iglesias et al. 2001, Jung et al. 2005, 2007) as well as the primary role of Neoparamoeba perurans in aetiology of AGD (Young et al. 2007, 2008) was clearly demonstrated. Less attention has been paid to component causes of both infections and possible mixed infec- 
tions by these 2 groups of free-living organisms that possess a fascinating amphizoic way of life. Histological examination of mixed infections of both organisms makes it possible to determine trophozoites of Neoparamoeba spp. in gill tissue owing to the presence of a kinetoplastid endosymbiont in the vicinity of the amoeba nucleus (Dyková \& Novoa 2001). Ciliates can be recognized in histological sections, but the morphological features distinguishing individual genera of scuticociliates are not detectable in sectioned material (Dyková \& Figueras 1994, Ramos et al. 2007) and, therefore, the isolation of ciliates facilitating their morphological and molecular characterization is important.

The interpretation of results of staining procedures might be ambiguous as, for example, in the case of stomatogenesis (Ma et al. 2004); therefore, molecular characterization is desirable to make a proper diagnosis in ciliates. Unfortunately, sequences representing many species, even those that were established in culture, are missing. This applies also to Uronema nigricans, which is found to cause fatal encephalitis in southern bluefin tuna (Munday et al. 1997, Crosbie \& Munday 1999). The results of attempts by Soldo et al. (1981) to characterize nucleic acids of this ciliate are incomparable with current data in the GenBank database. The subclass Scuticociliatia Small, 1967 is considered basically monophyletic as determined with SSU rRNA gene sequences (Lynn \& Strüder-Kypke 2005); nevertheless, a call for more sequences is urgent because classification based on morphostatic and stomatogenetic oral features receives little support from SSU rRNA gene sequences (Lynn 2008).

To date, only environmental isolates and strains of Uronema marinum derived from them have been available for phylogenetic analysis. Based on the results of the present study, the clade of $U$. marinum also now contains sequences of strains isolated from gills of 2 fish species (turbot and Atlantic salmon) that were collected in geographically distant localities. Although there is no guarantee that the ciliate found in mixed infections with Neoparamoeba sp. (Table 1) is $U$. marinum, the sequences obtained can be used in designing specific probes. These, together with species-specific Neoparamoeba probes, can help in pathogenetic studies of mixed infections of both agents or in retrospective disease outbreak surveys and casecontrol studies. The search for pathogenic species of both groups of organisms continues due to their cosmopolitan distribution and possible effect on the economy of fish farms.

Acknowledgements. We thank P. Crosbie and N. Young of the University of Tasmania, Launceston, Tasmania, Australia, for providing samples of gill tissue from Atlantic salmon. Financial support was provided by the Grant Agency of the
Czech Republic (Project No. 524/09/0137), Ministry of Education, Youth and Sports of the Czech Republic (MSM 6007665801) and research projects of the Institute of Parasitology, Biology Centre of the Academy of Sciences of the Czech Republic (Z60220518 and LC522)

\section{LITERATURE CITED}

Alvarez-Pellitero P, Palenzuela O, Padrós F, Sitjà-Bobadilla A, Riaza A, Silva R, Arán J (2004) Histophagous scuticociliatids (Ciliophora) parasitizing turbot Scophthalmus maximus: morphology, in vitro culture and virulence. Folia Parasitol (Praha) 51:177-187

Barta JR, Martin DS, Liberator PA, Dashkewitz M and others (1997) Phylogenetic relationships among eight Eimeria species infecting domestic fowl inferred using complete small subunit ribosomal DNA sequences. J Parasitol 83: 262-271

Bassleer G (1983) Uronema marinum, a new and common parasite on tropical salt-water fishes. Freshw Mar Aquar 6: $14 \& 78-79$

> Cawthorn RJ, Lynn DH, Despres B, MacMillan R, Maloney R, Loughlin M, Bayer R (1996) Description of Anophryoides haemophila n.sp. (Scuticociliatida: Orchitophryidae), a pathogen of American lobsters Homarus americanus. Dis Aquat Org 24:143-148

Cheung PJ, Nigrelli RF, Ruggieri GD (1980) Studies on the morphology of Uronema marinum Dujardin (Ciliatea: Uronematidae) with a description of the histopathology of the infection in marine fishes. J Fish Dis 3:295-303

Coleman AW, Vacquier VD (2002) Exploring the phylogenetic utility of ITS sequences for animals: a test case for abalone (Haliotis). J Mol Evol 54:246-257

Crosbie PBB, Munday BL (1999) Environmental factors and chemical agents affecting the growth of the pathogenic marine ciliate Uronema nigricans. Dis Aquat Org 36: 213-219

Dragesco A, Dragesco J, Coste F, Gasc C, Romestand B, Raymond JC, Bouix G (1995) Philasterides dicentrarchi n.sp. (Ciliophora, Scuticociliatida), a histophagous opportunistic parasite of Dicentrarchus labrax (Linnaeus, 1758), a reared marine fish. Eur J Protistol 31:327-340

Dunthorn M, Eppinger M, Schwartz MVJ, Schweikert M, Boenigk J, Katz LA, Stoeck T (2009) Phylogenetic placement of the Cyrtolophosididae Stokes, 1888 (Ciliophora; Colpodea) and neotypification of Aristerostoma marinum Kahl, 1931. Int J Syst Evol Microbiol 59:167-180

Dyková I, Figueras A (1994) Histopathological changes in turbot Scophthalmus maximus due to a histophagous ciliate. Dis Aquat Org 18:5-9

Dyková I, Novoa B (2001) Comments on diagnosis of amoebic gill disease (AGD) in turbot, Scophthalmus maximus. Bull Eur Assoc Fish Pathol 21:40-44

> Dyková I, Figueras A, Novoa B (1999) Epizoic amoebae from the gills of turbot Scophthalmus maximus. Dis Aquat Org 38:33-38

Dyková I, Nowak B, Pecková H, Fiala I, Crosbie P, Dvofiáková H (2007) Phylogeny of Neoparamoeba strains isolated from marine fish and invertebrates as inferred from SSU rDNA sequences. Dis Aquat Org 74:57-65

> Dyková I, Fiala I, Pecková H (2008) Neoparamoeba spp. and their eukaryotic endosymbionts similar to Perkinsela amoebae (Hollande, 1980): coevolution demonstrated by SSU rRNA gene phylogenies. Eur J Protistol 44:269-277

> Fernández-Galiano D (1994) The ammoniacal silver carbonate method as a general procedure in the study of proto- 
zoa from sewage (and other) waters. Water Res 28: 495-496

Foissner W (1991) Basic light and scanning electron microscopic methods for taxonomic studies of ciliated protozoa. Eur J Protistol 27:313-330

Hall TA (1999) BioEdit: a user-friendly biological sequence alignment editor and analysis program for Windows 95/98/NT. Nucleic Acids Symp Ser 41:95-98

Iglesias R, Paramá A, Álvarez MF, Leiro J, Fernández J, Sanmartín ML (2001) Philasterides dicentrarchi (Ciliophora, Scuticociliatida) as the causative agent of scuticociliatosis in farmed turbot Scophthalmus maximus in Galicia (NW Spain). Dis Aquat Org 46:47-55

$>$ Jung SJ, Kitamura SI, Song JY, Joung IY, Oh MJ (2005) Complete small subunit rRNA gene sequence of the scuticociliate Miamiensis avidus pathogenic to olive flounder Paralichthys olivaceus. Dis Aquat Org 64:159-162

Jung SJ, Kitamura SI, Song JY, Oh MJ (2007) Miamiensis avidus (Ciliophora: Scuticociliatida) causes systemic infection of olive flounder Paralichthys olivaceus and is a senior synonym of Philasterides dicentrarchi. Dis Aquat Org 73: $227-234$

Kim SM, Cho JB, Kim SK, Kwon SR, Nam YK, Kim KH (2004a) Occurrence of scuticociliatosis in olive flounder Paralichthys olivaceus by Philasterides dicentrarchi (Ciliophora: Scuticociliatida). Dis Aquat Org 62:233-238

Kim SM, Cho JB, Lee EH, Kwon SR, Kim SK, Nam YK, Kim KH (2004b) Pseudocohnilembus persalinus (Ciliophora: Scuticociliatida) is an additional species causing scuticociliatosis in olive flounder Paralichthys olivaceus. Dis Aquat Org 62:239-244

Larkin MA, Blackshields G, Brown NP, Chenna R and others (2007) Clustal W and Clustal X version 2.0. Bioinformatics 23:2947-2948

Lynn DH (2008) The ciliated Protozoa: characterization, classification, and guide to the literature, 3rd edn. Springer, Dordrecht

Lynn DH, Strüder-Kypke M (2005) Scuticociliate endosymbionts of echinoids (Phylum Echinodermata): phylogenetic relationships among species in the genera Entodiscus, Plagiopyliella, Thyrophylax and Entorhipidium (Phylum Ciliophora). J Parasitol 91:1190-1199

Ma H, Song W, Gong J, Warren A (2004) Reconsideration of stomatogenesis in Uronema marinum Dujardin, 1841 dur-

Editorial responsibility: Dieter Steinhagen,

Hannover, Germany ing asexual division (Protozoa: Ciliophora: Scuticociliatida). Acta Zool Sin 50:823-827

Munday BL, O'Donoghue PJ, Watts M, Rough K, Hawkesford T (1997) Fatal encephalitis due to scuticociliate Uronema nigricans in sea-caged, southern bluefin tuna Thunnus maccoyii. Dis Aquat Org 30:17-25

> Paramá A, Iglesias R, Álvarez MF, Leiro J, Aja C, Sanmartín ML (2003) Philasterides dicentrarchi (Ciliophora, Scuticociliatida): experimental infection and possible routes of entry in farmed turbot (Scophthalmus maximus). Aquaculture 217:73-80

Paramá A, Arranz JA, Álvarez MF, Sanmartín ML, Leiro J (2006) Ultrastructure and phylogeny of Philasterides dicentrarchi (Ciliophora, Scuticociliatia) from farmed turbot in NW Spain. Parasitology 132:555-564

Ramos MF, Costa AR, Barandela T, Saraiva A, Rodrigues PN (2007) Scuticociliate infection and pathology in cultured turbot Scophthalmus maximus from the north of Portugal. Dis Aquat Org 74:249-253

> Rossteuscher S, Wenker C, Jermann T, Wahli T, Oldenberg E, Schmidt-Posthaus H (2008) Severe scuticociliate (Philasterides dicentrarchi) infection in a population of sea dragons (Phycodurus eques and Phyllopteryx taeniolatus). Vet Pathol 45:546-550

Soldo AT, Merlin EJ, Godoy GA (1981) Nucleic acids of the marine ciliate Uronema nigricans, Pc. J Gen Microbiol 123:259-267

Stamatakis A (2006) RaxML-VI-HPC: maximum likelihoodbased phylogenetic analyses with thousands of taxa and mixed models. Bioinformatics 22:2688-2690

Sterud E, Hansen MK, Mo TA (2000) Systemic infection with Uronema-like ciliates in farmed turbot, Scophthalmus maximus (L.). J Fish Dis 23:33-37

Swofford DL (2001) PAUP*. Phylogenetic analysis using parsimony (*and other methods), Version 4. Sinauer Associates, Sunderland, MA

Young ND, Crosbie PBB, Adams MB, Nowak BF, Morrison RN (2007) Neoparamoeba perurans n. sp. an agent of amoebic gill disease in Atlantic salmon (Salmo salar L.). Int J Parasitol 37:1469-1481

> Young ND, Dyková I, Nowak BF, Morrison RN (2008) Development of a diagnostic PCR to detect Neoparamoeba perurans, agent of amoebic gill disease (AGD). J Fish Dis 31:285-295

Submitted: June 15, 2009; Accepted: October 19, 2009

Proofs received from author(s): January 29, 2010 